\title{
The selection of the best Olympic place for Turkey using an integrated MCDM model
}

\author{
Coşkun Karaca ${ }^{a}$, Alptekin Ulutaş̧, Gül Yamaner ${ }^{\mathrm{c}}$ and Ayşe Topal ${ }^{\mathrm{d}^{*}}$
}

${ }^{a}$ Finance Department, Cumhuriyet University, Sivas, 58000,Turkey

${ }^{b}$ International Trade and Logistics Department, Cumhuriyet University, Sivas, 58000, Turkey

${ }^{c}$ Coaching Education Department, Hitit University, Çorum, 19030,Turkey

${ }^{d}$ Operation Management and Marketing Department, Niğde Ömer Halisdemir University, Niğde, 51000, Turkey

\section{H R O N I C L E}

Article history:

Received March 23, 2018

Received in revised format:

May 10, 2018

Accepted May 24, 2018

Available online

May 24, 2018

Keywords:

Selection of Olympic Games Place

Entropy Method

COPRAS Method

\begin{abstract}
A B S T R A C T
Hosting Olympic Games is a significant opportunity for every country and her metropolitan cities. Olympics offer several benefits to the Host countries and cities such as introducing cultural assets of the country to the world and increasing economic value of the country and city Olympics held. Countries and cities wishing to host Olympic Games have to prove that they have the qualifications to be host of these games. The International Olympic Committee (IOC) has identified 5 main criteria and 22 sub-criteria to determine the objectivity measure of this adequacy. These criteria are in conflict with each other so multi-criteria decision making (MCDM) methods can be useful to determine the best host country and its city for Olympic Games. In this study, an integrated MCDM model is proposed to determine the best metropolitan city in Turkey for hosting of the Olympic Games. The contribution of this study is that there are very few studies related to the selection of hosting places for Olympic Games using MCDM methods. The results of the integrated model show that Antalya is the best metropolitan host for Olympic Games.
\end{abstract}

\section{Introduction}

Hosting the Olympic Games is considered as an opportunity for the city Olympics held to be known more worldwide. In addition to providing many economic opportunities for the host country, the Olympics also ensures that the people of the host country are more intertwined with the sport culture. According to Baron de Coubertin, who is recognized to be the originator of the Olympic Games, the Olympics is one of the most important organizations in the world as it will provide the universalization of three important values such as "international understanding, brotherhood and peace" (Crowther, 1999).

Generally, the reason why the countries and their cities would like to be a host to the Olympics is not only to create three important values expressed by Coubertin but also because of its contribution to the

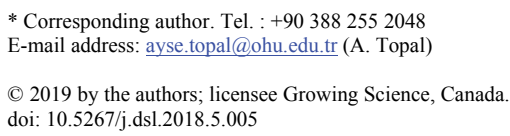


urban development. Therefore, the Olympics including arts, sports and sharing culture create the opportunities for people all around the world to visit different places and bring people together.

Any government that wishes to hold such a huge organization in its country has to make significant efforts to become a part of it. A candidate to be the host country has to prove that it has the necessary qualifications for the Games. In order to provide an objective measure of this sufficiency, the International Olympic Committee (IOC) has identified 22 different sub-criteria within the scope of 5 the main criteria. The Committee uses a number of objective and subjective criteria as a basis, such as the number and size of facilities, geographical and cultural factors, meteorology, accommodation, transportation, medical services, safety and security, technological infrastructure, government and public support. Those who meet these criteria have an increased chance to move from being a candidate to being a host.

This study aims to estimate the most suitable city for the Summer Olympic Games in Turkey within the scope of the criteria mentioned earlier. The most suitable city among the metropolises in Turkey for the Olympic Games will be estimated by performing an analysis via an integrated model including Entropy method and Complex Proportional Assessment (COPRAS). The contribution of this study is that there are very few studies used MCDM methods to determine hosting city for Olympic Games before. This study will fill this research gap in the literature.

\section{The Importance of the Olympic Games for the Cities: Olympic Legacy}

The Olympic Games has a positive effect on the city's community, image and infrastructure due to the significant opportunities provided by the Olympic Games for improving the city landscape and society and for leaving to the city important legacies. Urban development and sports development of the city in addition to the economic, environmental and social benefits are expected opportunities from the Olympic Games ("Beyond 2024," n.d.).

In addition to the opportunities above, Olympic Games also has a positive effect on social relations in the city by educating residents about social relations and integrating the Olympic values and the city policies. It is significantly important for the stakeholders who participate in the Olympic Games planning and operations to take all the impacts of actions and policies into account in order to gain legacies from Olympic Games ("Beyond 2024," n.d.).

According to Jacques Rogge who is IOC former President; "Legacies are the lasting outcomes of our efforts. They bring to life the Olympic values of excellence, friendship and respect. ... Creating sustainable legacies is a fundamental commitment of the Olympic Movement. It is our obligation. ... Every city that hosts the Olympic Games becomes a temporary steward of the Olympic Movement. It is a great responsibility. Host cities must ensure the continuity of a unique and universal event. ... It is also a great opportunity. Host cities capture worldwide attention. Each has a once-in-a-lifetime chance to showcase the celebration of the human spirit. And each creates a unique set of environmental, social and economic legacies that can change a community, a region, and a nation forever" (Moroney, n.d.).

The Olympic Games leave two types of legacies to the cities. One is physical legacies such as buildings and infrastructures; another is non-physical such as involvement of local people to Olympic Games tasks, pride of holding a major event, environmental and cultural awareness, introducing different skills to the local workforce. The scope of legacies has been moved to whole host region and country from host city ("Beyond 2024," n.d.). It can be seen in Table1 examples of tangible and intangible legacies. Legacies left by the Olympic Games, whether tangible or the intangible are important for social development of the host city, region and country for catering a civilized and modern society (Scandizzo \& Pierleoni, 2017). Tangible benefits, firstly, bring to the host city a contribution from the International Olympic Committee (for the summer games over 1 billion dollars), to cover the operating costs of the event. This boost in expenditure attracts other public or private investment, which, in its turn, may enable the city to improve the standards of its plants and infrastructures. In macroeconomic terms, the Games is an opportunity for the cities to attract investments and create new trade relations. The Games 
positively affect job creation and economic growth of the host city and region (Scandizzo \& Pierleoni, 2017; Essex \& Chalkley, 1999; State of Utah, 2000; Ference Weicker \& Company, 2002; Young, 2003).

Table 1

The Tangible and Intangible Legacies of the Olympic Games

\begin{tabular}{lll}
\hline Tangible legacies & Intangible legacies \\
\hline - New and/or upgraded sporting and non-sporting & - National pride \\
facilities & - Improved policies and practices \\
- New and/or improved transport infrastructure & - New and enhanced workforce skills and \\
- Urban upgrading and beautification & knowledge \\
- Telecommunications infrastructure & - Attitudinal changes \\
& - New methods and best practices in construction, \\
& event management and business \\
& - City/country worldwide recognition \\
& - Olympic education \\
& - Enviscovery of national culture \\
&
\end{tabular}

Source: IOC, $2018 b$ (“Beyond 2024,” n.d.).

Intangible benefits derive from the prestige for presenting to the world the capability of hosting a major event like the Games. For example, it was shown that the Sydney 2000 Games enriched the brand of Australia internationally and consequently increased tourism in Australia in the report of the Government of New South Wales (NSW) (Price Waterhouse Coopers, 2002). In this respect, Morphet (1996) stated that media is significantly important for introducing the host city or region to the majority. Ritchie and Smith's (1991) study showed that the 1988 Winter Olympic Games had a great effect on Calgary in terms of promotion of Calgary in Europe and the United States. It had been known much better than other Canadian cities in in Europe and the United States. Similar to that, the number of tourists in Atlanta increased significantly after the Centennial Olympic Games had been held. During the Games, Atlanta welcomed around two million visitors and around 3.5 million people in 214 countries watched Atlanta on television (Scandizzo \& Pierleoni, 2017; Stevens \& Bevan, 1999).

Today, the Olympic Games are the most comprehensive and profitable marketing example on the global scale (Schmitz, 2004). This profitability is due to the Olympics being the most popular and most watched organization in the world. Televisions sacrifice huge budgets to broadcast this organization. For example, NBC paid \$ 3.5 billion to get five Olympic demonstrations during the 2000-2008 seasons. Undoubtedly, this investment extremely turns back to the television channels, because the prices paid by advertisers during broadcasting are very high (Lee, 2005).

It has been shown in the literature that the jobs created by the Games have a positive effect on the host city and region in terms of unemployment (Miguelez \& Carrasquer, 1995). A large number of jobs are created not only for directly associated professions such as event management or sports management but also for professions in the tourism or retail industries due to the increasing visitors during the Games and professions in the construction industry because of the need for building new venues and infrastructures for the Games. For example, \$2 million was invested into the Games for the 1996 Olympic Games in Atlanta and in return, a large number of jobs were created during the Games and a cumulative economic impact of $\$ 5.1$ billion was made (Stevens \& Bevan, 1999). Similar to Atlanta, Barcelona had positive experiences from being the host city of the 1992 Olympic Games such as a decrease in unemployment rate from $18.4 \%$ to $9.6 \%$ between 1986 and 1992 (Scandizzo \& Pierleoni, 2017; Brunet, 1995). Literature also presents the media effects on the tourism of the host city or region (Hughes, 1993; Kang \& Perdue, 1994; Kemp, 2002; Tudge, 2003) and the effect of the Games on the city community in terms of social standards (Eitzen, 1996; Lenskyj, 2000). Infrastructural and urban regeneration for games create important business opportunities for the people of the country and local community. For example, it is estimated that 29,250 people will be employed in 6 years before the 
game and 30,300 people will be provided jobs during the games in a report analysed benefits of Boston in case of holding Olympics 2024. Although the number of employment will change depending on whether the investments will be made with domestic supply or not, an additional business opportunity will emerge for approximately 3,250-5,000 people per year (Bazelon et al., 2015).

Preparations for the organization, transportation infrastructure, and urban landscape offer many new investment opportunities. For example, thanks to the Olympic Games in Seoul, the city made significant developments to prevent air pollution, control waste and increase water quality. Expenditures for the Roman Olympics have provided a modern water system to the city, the city has had acquired a new air space and the city has had a unique landscape (Essex \& Chalkley, 1999). Spain, on the other hand, has taken the advantage of Barcelona Olympics to eliminate the insufficient infrastructure left from Franco's period (Liao \& Pitts, 2006). Despite all these benefits, it is known that the Olympics have several adverse effects on cities. Although the Olympic Committee has established certain criteria to prevent the games from damaging the bio-diversity and the environment, New Wales State excused all investments for the Sydney Olympics from the "Environmental Impact Assessment" procedure (Hall, 2006). Moreover, Burgan and Mules (1992) and Gelan (2003) reported that there were increase in crime rates and vandalism during the Olympic Games. Also, discomfort created by construction and infrastructure development to build Olympic Games venues had a negative effect on city residents (Cashman \& Darcy, 2008) in addition to the increased residential prices with the Games (Collins, 1991). Miller and Spoolman (2011) noted that the need for various infrastructure and services such as transport, housing, water and energy increase significantly during the Games due to the high number of visitors residing in the city at that time (Scandizzo \& Pierleoni, 2017). Finally, the Olympics also may escalate the social problems being experienced before the Games and intensify existing divisions in the community (Ruthheiser, 2000).

\section{The Evaluation Process of Olympic City}

The officials of the cities to be a candidature for the Olympic City initiate a formal Candidature Process after finding out necessary information about planning the Games in invitation phase at the beginning. To assure that the legacies from Games will still be effective in the long-term, cities are supported in determining of the city values, proposal examination and finding solutions to expected problems to carry out Games perfectly while not compromising either athletes performing venues or cities' and regions' needs. There are three stages that form the Candidature Process 2024, which are ("Olympic Games," n.d.):

\section{- Stage 1: Vision, Games Concept and Strategy}

Vision of Games, plans of concepts and legacies are presented by the candidate cities at this stage. The support of nation and stakeholders will be seek by the candidate cities when the main concept of Olympic Games and venues are developed to create sustainable plans for urban development and legacies.

\section{- Stage 2: Governance, Legal and Venue Funding}

At this stage, the candidate cities need to show that they have required legal structure and financial resources to carry out Games. To find out the challenges and opportunities provided Games, Evaluation Commission Working Group appointed by the IOC will assess the support given to the cities by public and private sector, legal and governance structures.

\section{- Stage 3: Games Delivery, Experience and Venue Legacy}

Stage 3 will assess how the Games will be carried out by the cities and how sustainability in the legacy will be ensured. At this stage, in order to assure that Games will be delivered successfully, Evaluation Commission will evaluate all operations involved in Games in addition to the evaluation of the Games experience and legacy planning. 
The next step is the choice of the host city. At this step, the Olympic Candidature Process will be carried out and the candidate cities will make several presentations during the Process. On the Elections Day at the final of the Olympic Candidature Process, the final presentation will be performed by the cities to the IOC members. The host city for the Games is elected by the IOC members after the presentations are carried out and a report created by the Evaluation Commission evaluating the presentations. After the election, the IOC will make a contract (the Host City Contract) with selected city for hosting the Games. Evaluation Commission aims to assess the Cities' Candidature File Submissions. The authenticity of information given by the candidate cities is examined, cities' ability to carry out the Games successfully is reviewed, the feasibility of the proposed plans presented by the cities and the probability of positive legacies to be left by the Games are analysed by the Commission. To make sure analysis is carried out correctly, the Evaluation Commission arranges visits to the candidate cities at Stage 3 (“Olympic Games," n.d.).

\section{The Evaluation Criteria of Olympic City}

There are solid standards put by the IOC to determine which cities qualify to be assessed for the Olympic Games. Cities are assessed from various points from their history and infrastructures whether they can handle numerous people who visit the city during the Games to their potential of handling all the construction due to the Games (Warner, 2016). Seventy copies of a hundred pages questionnaire which includes all points for need to be presented to the IOC. This questionnaire must be filled accurately and concisely. It also must include all the plans of cities for the Games and current situation of the cities. There are various sections in the questionnaire such as the country, region and city characteristics, facilities (medical, transport, accommodation, media etc.), immigration services, legal structure, support given to the cities by public and private institutions and so on (Pearce, 2015). The criteria that the Commission considers in evaluating the cities are shown in Table 2.

\section{Table 2}

Evaluation Criteria for Selection of Host City

\begin{tabular}{|c|c|c|}
\hline $\begin{array}{l}\text { Stage 1: Vision, Games Concept and } \\
\text { Strategy }\end{array}$ & $\begin{array}{l}\text { Stage 2: Governance, Legal and Venue } \\
\text { Funding }\end{array}$ & $\begin{array}{l}\text { Stage 3: Games Delivery, Experience and } \\
\text { Venue Legacy }\end{array}$ \\
\hline $\begin{array}{l}\text { 1.1. Vision and Games Concept } \\
\text { - Vision } \\
\text { - Games Features and Operational } \\
\text { - Concepts } \\
\text { - Venue Concept } \\
\text { - Olympic Village } \\
\text { - DatMPC } \\
\text { - Meteorology } \\
\text { 1.2. Legacy and Long-Term Plan } \\
\text { Integration and Alignment } \\
\text { - Existing City/Region Long-Term Plan } \\
\text { Alignment } \\
\text { - Benefits for the Olympic/Paralympic } \\
\text { Movement } \\
\text { - Legacy } \\
\text { 1.3. General Infrastructure and Capacity } \\
\text { Analysis } \\
\text { - Population statistics } \\
\text { - Accommodation, Airport, Transport } \\
\text { - Energy, Telecommunications } \\
\text { - Medical services and emergency } \\
\text { response } \\
\text { 1.4. Country Analysis } \\
\text { - Political and Governance Framework } \\
\text { - Safety and Security } \\
\text { - Support for the Games } \\
\text { - Legal Framework } \\
\text { - Economic Analysis, Finance }\end{array}$ & $\begin{array}{l}\text { 2.1. Governance Structure } \\
\text { - Games delivery } \\
\text { - Legacy delivery } \\
\text { 2.2 Legal, Customs and Immigration } \\
\text { - Games-related legislation and } \\
\text { regulation } \\
\text { - Taxes } \\
\text { - Advertising Control and anti-ambush } \\
\text { measures } \\
\text { - Host Country Entry Regulations } \\
\text { - Games workforce regulations } \\
\text { 2.3 Support and Venue Funding } \\
\text { - Support for the Games } \\
\text { - Venue Funding } \\
\text { 2.4 Guarantees }\end{array}$ & $\begin{array}{l}\text { 3.1 Games Concept (Update) } \\
\text { 3.2 Games and Athlete Experience } \\
\text { 3.3 Sport } \\
\text { 3.4 Venues } \\
\text { - Olympic Village(s) } \\
\text { - Media Facilities } \\
\text { 3.5 Paralympic Games } \\
\text { 3.6 Sustainability } \\
\text { 3.7 Games Safety and Security } \\
\text { 3.8 Accommodation } \\
\text { 3.9 Transport } \\
\text { 3.10 Finance } \\
\text { 3.11 Marketing } \\
\text { 3.12 Transition Plan } \\
\text { 3.13 Guarantees }\end{array}$ \\
\hline
\end{tabular}


The main focus of Stage 1 which is called "The Vision, Games Concept and Strategy Stage" is on assessment of strategic and primary capacity. Within this scope, the cities are asked to make a statement about the proposed concept of the Games showing what kind of framework will be created for the Games and its legacies. The Stage 2 "Governance, Legal and Venue Funding Stage" focus on the support given by government and non-government institutions to the Olympic Games to meet the needs of the Games. At this stage, the candidate cities need to show that they have the support of public institutions evidenced with necessary paperwork in order to propose that they have enough support to handle all the necessities of a major event like Olympic Games. The focus of Stage 3 "The Games Delivery, Experience and Venue Legacy Stage" is on the risks and opportunities from delivering the Games. The Stage 1 and Stage 2 findings present necessary context needed to do any change at this stage. This stage will focus on how legacies of Games should be delivered to the local people to maximize benefits. The evaluation of candidate cities for the Games will be performed with the use of sustainability criteria (International Olympic Committee, 2015).

\section{Selection of the Optimal Olympic Place Choice in Turkey}

\subsection{Criteria in the Analysis}

When the criteria were analysed, a classification similar to the one made by the IOC was used. It is: i) General Concept of Games, Facilities and Sports Experience, ii) Environment, Meteorology, Accommodation and Transportation, iii) Medical Services and Safety, iv) Telecommunication, Energy and Economy. Table 3 shows these criteria, and sub-criteria of these criteria.

Table 3

Main and Sub Criteria Used in Analysis

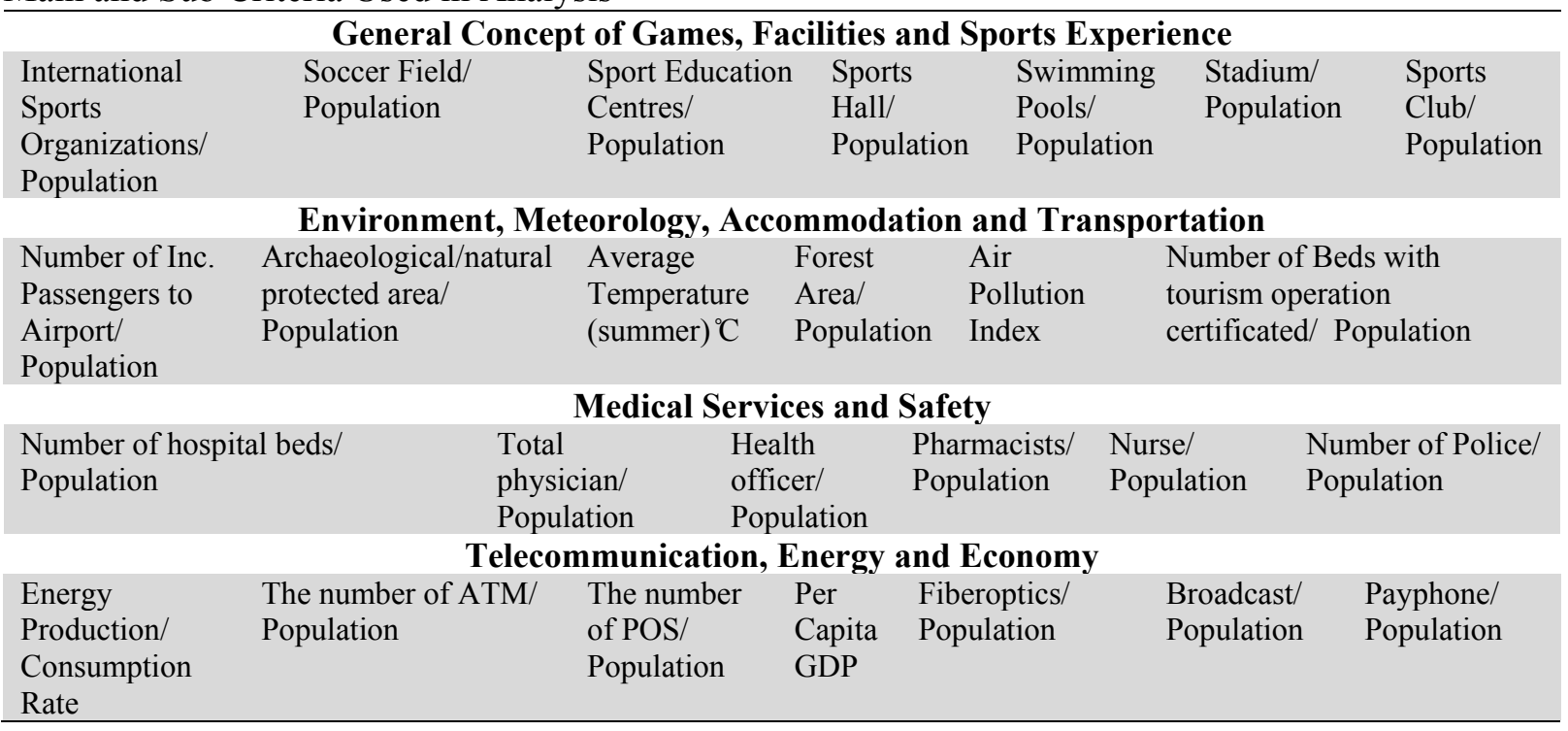

When all other data are obtained except for the four of them (average temperature, air pollution index, energy production and per capita GDP), as seen in the table, the data for each criterion is divided by the population of the city, and these data have been included in the analysis as the amount per capita. This is done to eliminate the comparative advantage of high-populated cities have, and to standardize the performance values of the criteria.

Criteria for general concept of games, facilities and sports experience show city-specific sports organizations and the number of facilities. The international sports organizations data, first one of the sub-data, show the number of international competitions and sports contests held in the cities in which more than one country is participated. The criteria soccer field, sport education centres, sports hall, swimming pool, stadium and sports club show how many of these the cities have. 
Environment, meteorology, accommodation and transportation criteria measure the availability of cities in terms of accommodation and transportation. One (number of incoming passengers to airport) of the 6 sub-criteria under this criterion shows the transportation-specific data of the cities, while the other five (archaeological/natural protected area, average temperature, forest area, air pollution index, number of beds with tourism operation certificated) show the accommodation-specific data such as tourism and the environment.

In sub-criteria contained in medical services and safety, data related to health and safety were analysed. There is a positive correlation between these data and the selection of the location for the Olympics. In other words, as the number of hospital beds, physicians, pharmacists, nurses and police per capita increases, the chance for the city to hold Olympics increases.

In the telecommunication, energy and economy criteria, the sufficiency of cities in terms of communication, energy and economy are measured. The sub-criterion energy production and consumption rate measures whether or not the city's energy supply is sufficient for city's energy demand during Olympics. This ratio being greater than 1 indicates that the energy supply in the city is above energy demand of the city and it shows that city has necessary energy sources to meet increasing energy demand during Olympics. Again, the city's economic self-sufficiency is measured by three criteria (the number of ATM, the number of POS, per capita GDP) that cities have. If these criteria are met at a high level, then it means that the economic self-sufficiency per capita is also high. The other three criteria (fiberoptics, broadcast, payphone) in which data per capita are used, show the sufficiency of the city for communication.

\subsection{Methodology}

In this study, the integrated model including Entropy method and COPRAS method will be used to select the most suitable place in Turkey for Olympic Games. Entropy method is used to obtain objective weights of criteria.

Entropy method can be summarised as (Wang \& Lee, 2009; Li et al., 2011):

Step 1: Structuring Decision Matrix (D) including Olympic place alternatives and criteria:

$$
D=\left[x_{i j}\right]_{m \times n}=\left[\begin{array}{cccc}
x_{11} & x_{12} & \cdots & x_{1 n} \\
x_{21} & x_{22} & \cdots & x_{2 n} \\
\vdots & \vdots & \vdots & \vdots \\
x_{m 1} & x_{m 2} & \cdots & x_{m n}
\end{array}\right]
$$

In Eq. (1), $x_{i j}$ denotes the performance of $i$ th Olympic place alternative on $j$ th criterion.

Step 2: Values in the decision matrix are standardized by using Eq. (2) (beneficial criteria) and Eq.

(3) (non-beneficial criteria). In Eqs. (2-3), $r_{i j}$ is the standardised form of $x_{i j}$.

$$
\begin{aligned}
r_{i j} & =\frac{x_{i j}}{\max _{j}\left(x_{i j}\right)} \\
r_{i j} & =\frac{\min _{j}\left(x_{i j}\right)}{x_{i j}}, \min _{j}\left(x_{i j}\right) \neq 0
\end{aligned}
$$

Step 3: Standardized values are normalized by using Eq. (4) and normalized matrix is structured. In Eq. (4), $f_{i j}$ denotes normalized value of $r_{i j}$.

$$
f_{i j}=\frac{r_{i j}}{\sum_{i=1}^{m} r_{i j}}
$$

Step 4: After normalization process, entropy value for each criterion can be calculated by using below equation. In Eq. (5), $E_{j}$ is the entropy value of $j$ th criterion. 
$E_{j}=-\frac{\sum_{i=1}^{m} f_{i j} \ln \left(f_{i j}\right)}{\ln (m)}$

Step 5: In final step, the objective weight of each criterion can be calculated by using Eq. (6).

$$
w_{j}=\frac{1-E_{j}}{\sum_{j=1}^{n}\left(1-E_{j}\right)} .
$$

The weights of criteria will be transferred to COPRAS method.

After obtaining criteria weights, COPRAS method will be used to evaluate the performance of alternatives. COPRAS method developed by Zavadskas and Kaklauskas (1996) is used to determine the performance of alternatives. COPRAS method can be summarized in six steps below.

Step 1: The first step of COPRAS is to construct the decision matrix. The decision matrix, which is considered in COPRAS, is indicated in Eq. (1).

Step 2: In step 2, the normalized matrix will be calculated. Normalized matrix was calculated by using Eq. (4) in Entropy method. Same normalized matrix will be used in COPRAS.

Step 3: In step 3, the normalized values are multiplied by the weights of criteria (obtained in Entropy method). In Eq. (7), $x_{i j}^{\prime}$ indicates the weighted normalized value.

$$
x_{i j}^{\prime}=f_{i j} \times w_{j}
$$

Step 4: In step 4, beneficial and non-beneficial criteria are summed among themselves. Beneficial criteria are summed by using Eq. (8), on the other hand; non-beneficial criteria are summed by using Eq. (9).

$$
\begin{aligned}
& S_{i}^{+}=\sum_{j=1}^{o} x_{i j}^{*} \\
& S_{i}^{-}=\sum_{j=o+1}^{n} x_{i j}^{*}
\end{aligned}
$$

for beneficial criteria

for non-beneficial criteria

Step 5: After step 4, the relative importance $\left(Q_{i}\right)$ of each alternatives can be calculated by using following equation:

$$
Q_{i}=S_{i}^{+}+\frac{\sum_{i=1}^{m} S_{i}^{-}}{\left(S_{i}^{-} \times \sum_{i=1}^{m} \frac{1}{S_{i}^{-}}\right)}
$$

Step 6: After determining the relative importance $\left(Q_{i}\right)$ of each alternatives, total performance score $\left(T_{i}\right)$ can be obtained by following equation:

$$
T_{i}=\left(\frac{Q_{i}}{Q_{\max }}\right)
$$

All metropolitan cities of Turkey will be ranked with respect to total performance score $\left(T_{i}\right)$. Next section presents the application of the integrated model to select the best metropolitan as an Olympic Place. 


\subsection{Application}

In the application section, the performance of 30 metropolitan with respect to 26 criteria will be evaluated by using Entropy method and COPRAS method. 25 out of 26 criteria are beneficial criteria and only one criterion (air pollution) is non-beneficial criterion. Data used in the evaluation process are given in Appendix A and B. First of all, Entropy method is used to obtain the weights of criteria. Table 4 indicates the weights of criteria obtained in Entropy Method.

Table 4

Criteria Weights

\begin{tabular}{lclc}
\hline Criteria & $w_{j}$ & Criteria & $w_{j}$ \\
\hline Swimming Pools & 0,018 & Total physician & 0,004 \\
Soccer Field & 0,036 & Nurse & 0,003 \\
Sport Education Centers & 0,032 & Health officer & 0,004 \\
Sports Hall & 0,022 & Pharmacist & 0,004 \\
Stadium & 0,034 & Number of hospital beds & 0,005 \\
International Sports Organizations & 0,058 & Number of Police & 0,002 \\
Sports Club & 0,009 & Payphone & 0,008 \\
Average Temperature oC (optim.20.6) & 0,006 & Broadcast & 0,001 \\
Air Pollution Index & 0,019 & Fiberoptics & 0,007 \\
Archaeological/Natural Protected Areas & 0,043 & Energy Production /Consumption Rate & 0,053 \\
Forest Area & 0,041 & The Number Of ATM & 0,012 \\
Number Of Beds With Tourism Operation Certificated & 0,202 & The Number of POS & 0,011 \\
Number of Inc. passengers to Airport & 0,351 & Per Capita GDP & 0,011 \\
\hline
\end{tabular}

After determination of the weights of criteria, these weights transfers to COPRAS. The results of COPRAS method are indicated in Table 5.

Table 5

The Results of COPRAS Method

\begin{tabular}{|c|c|c|c|c|c|c|}
\hline \multirow[b]{2}{*}{ Metropolitans } & \multicolumn{6}{|c|}{ Results } \\
\hline & $S_{i}^{+}$ & $S_{i}^{-}$ & $Q_{i}$ & $T_{i}$ & $100 \times T_{i}$ & Ranking \\
\hline Adana & 0,01603 & 0,0004 & 0,0169 & 0,0534 & 5,34 & 15 \\
\hline Ankara & 0,01172 & 0,0004 & 0,0126 & 0,0398 & 3,98 & 23 \\
\hline Antalya & 0,31591 & 0,0005 & 0,3166 & 1 & 100 & 1 \\
\hline Aydın & 0,0271 & 0,0006 & 0,0277 & 0,0875 & 8,75 & 3 \\
\hline Balıkesir & 0,0211 & 0,0006 & 0,0217 & 0,0685 & 6,85 & 9 \\
\hline Bursa & 0,01131 & 0,0004 & 0,0121 & 0,0382 & 3,82 & 26 \\
\hline Denizli & 0,01879 & 0,0003 & 0,0199 & 0,0629 & 6,29 & 12 \\
\hline Diyarbakır & 0,0116 & 0,0005 & 0,0123 & 0,0389 & 3,89 & 25 \\
\hline Erzurum & 0,02152 & 0,0007 & 0,022 & 0,0695 & 6,95 & 8 \\
\hline Eskişehir & 0,01962 & 0,001 & 0,02 & 0,0632 & 6,32 & 11 \\
\hline Gaziantep & 0,00939 & 0,0008 & 0,0098 & 0,031 & 3,1 & 28 \\
\hline Hatay & 0,01459 & 0,0009 & 0,015 & 0,0474 & 4,74 & 17 \\
\hline İstanbul & 0,01296 & 0,0009 & 0,0133 & 0,042 & 4,2 & 22 \\
\hline İzmir & 0,02241 & 0,0007 & 0,0229 & 0,0723 & 7,23 & 7 \\
\hline Kahramanmaraş & 0,01568 & 0,0004 & 0,0165 & 0,0521 & 5,21 & 16 \\
\hline Kayseri & 0,0166 & 0,0005 & 0,0173 & 0,0546 & 5,46 & 14 \\
\hline Kocaeli & 0,01169 & 0,0005 & 0,0124 & 0,0392 & 3,92 & 24 \\
\hline Konya & 0,01399 & 0,0006 & 0,0145 & 0,0458 & 4,58 & $18-19-20$ \\
\hline Malatya & 0,01941 & 0,0005 & 0,0201 & 0,0635 & 6,35 & 10 \\
\hline Manisa & 0,01659 & 0,0004 & 0,0174 & 0,055 & 5,5 & 13 \\
\hline Mardin & 0,01037 & 0,0025 & 0,0105 & 0,0332 & 3,32 & 27 \\
\hline Mersin & 0,01341 & 0,0003 & 0,0145 & 0,0458 & 4,58 & $18-19-20$ \\
\hline Muğla & 0,2125 & 0,0006 & 0,2131 & 0,6731 & 67,31 & 2 \\
\hline Ordu & 0,01269 & 0,0004 & 0,0135 & 0,0426 & 4,26 & 21 \\
\hline Sakarya & 0,02388 & 0,0003 & 0,025 & 0,079 & 7,9 & 4 \\
\hline Samsun & 0,02259 & 0,0004 & 0,0234 & 0,0739 & 7,39 & 5 \\
\hline Şanlıurfa & 0,00927 & 0,0008 & 0,0097 & 0,0306 & 3,06 & 29 \\
\hline Tekirdağ & 0,01415 & 0,0009 & 0,0145 & 0,0458 & 4,58 & $18-19-20$ \\
\hline Trabzon & 0,0228 & 0,0008 & 0,0232 & 0,0733 & 7,33 & 6 \\
\hline Van & 0,00804 & 0,0006 & 0,0086 & 0,0272 & 2,72 & 30 \\
\hline
\end{tabular}


The results of COPRAS show that Antalya is the most appropriate place for holding of Olympic Games. Muğla is the second most appropriate place followed by Aydın. In this analysis, only metropolitan cities were considered for selecting of the best place for Olympic Games.

\section{Conclusion and Future Research Directions}

Hosting the Olympic Games is a wonderful dream for many countries. Additionally, hosting these Games provides many benefits, such as economic opportunities for the host country and allowing the host country to carry its cultural heritages to the world. Countries which would like to take advantage of being hosting Olympic Games should provide their qualifications, which are required to be host of these Games. IOC has declared 5 main criteria and their 22 sub-criteria to identify the objectivity measure of this sufficiency. These criteria conflicting each other and motivates using MCDM for the selection of appropriate Olympics hosting country/city. In this study, the best metropolitan city in Turkey was estimated by using an integrated MCDM methods including Entropy method and COPRAS method. Entropy method has been used to obtain objective weights of criteria and COPRAS method was used to rank metropolitan cities with respect to their performance scores. In this study, Antalya was the most appropriate place for holding of Olympic Games. There were limited studies related to the selection of Olympic place by using MCDM methods in the literature, so this study has filled this gap in the literature. Future research can use different MCDM methods, such as TOPSIS, VIKOR, BWM, etc. to select the most appropriate place for hosting the Olympic Games. Additionally, future research can analyse different countries and cities to identify the most appropriate place for Olympic Games.

\section{References}

Brunet, F. (1995). An economic analysis of the Barcelona '92 Olympic Games: resources, financing, and impact. In The Keys to Success; Miquel, M. D., Botella, M., Eds.; Autonomous University of Barcelona: Barcelona, SPAIN.

Bazelon, C., Seth, P., Herscovici, S., Berkman, M., Sanderson, A. R., Humphreys, B., Floyd, J. J., \& Abasciano, M. P. (2015). Analysis of the Boston 2024 Proposed Summer Olympic Plans; The Brattle Group: Boston, NY, USA.

Burgan, B., \& Mules, T. (1992). Economic impact of sporting events. Annals of Tourism Research, 19(4), 700-710.

Cashman, R., \& Darcy, S. (2008). Benchmark Games: The Sydney 2000 Paralympic Games; Walla Walla Press: Sydney, AUSTRALIA.

Collins, M. F. (1991). The economics of sport and sports in the economy: some international comparisons. Progress in Tourism, Recreation and Hospitality Management, 3, 184-214.

Crowther, N. (1999). Sports, nationalism and peace in ancient Greece. Peace Review, 11(4), 585-589.

Eitzen, D. S. (1996). Classism in sport: the powerless bear the burden. Journal of Sport and Social Issues, 20(1), 95-105.

Essex, S., \& Chalkley, B. (1998). Olympic Games: catalyst of urban change. Leisure Studies, 17(3), 187-206.

Essex, S., \& Chalkley, B. (1999). Olympic locations and legacies: a study in geography and tourism. Pacific Tourism Review, 3(3-4), 185-200.

Ference Weicker \& Company (2002). Impact of 2010 Olympic Winter Games and Paralympic Games on Vancouver's Inner City Neighbourhoods Interim Report. Ference Weicker \& Company: Vancouver, CANADA.

Gelan, A. (2003). Local economic impacts: The British Open. Annals of tourism research, 30(2), 406425.

Hall, C. M. (2006). Urban entrepreneurship, corporate interests and sports mega-events: the thin policies of competitiveness within the hard outcomes of neoliberalism. The Sociological Review, 54, $59-70$. 
Hughes, H. L. (1993). Olympic tourism and urban regeneration. Festival Management and Event Tourism, 1(4), 157-162.

International Olympic Committee (2015). Candidature Questionnaire Olympic Games 2024. Retrieved from

https://stillmed.olympic.org/Documents/Host_city_elections/Candidature_Questionnaire_Olympic Games_2024.pdf.

Kang, Y. S., \& Perdue, R. (1994). Long-term impact of a mega-event on international tourism to the host country: a conceptual model and the case of the 1988 Seoul Olympics. Journal of International Consumer Marketing, 6(3-4), 205-225.

Kemp, J. D. (2002). Beyond the Games: Assessing the Impact of the 2002 Olympic Winter Games and the Future of Utah Tourism. Utah. Division of Travel Development: Salt Lake City, UT, USA.

Lenskyj, H. J. (2000). Inside the Olympic Industry: Power, Politics, and Activism. SUNY Press: Albany, NY, USA.

Lee, J. K. (2005). Marketing and promotion of the Olympic Games. The Sport Journal, 8(3).

Li, X., Wang, K., Liu, L., Xin, J., Yang, H., \& Gao, C. (2011). Application of the Entropy Weight and TOPSIS Method in Safety Evaluation of Coal Mines. Procedia Engineering, 26, 2085-2091.

Liao, H., \& Pitts, A. (2006). A brief historical review of Olympic urbanization. The International Journal of the History of Sport, 23(7), 1232-1252.

Miguelez, F., \& Carrasquer, P. (1995). The repercussion of the Olympic Games on labour. In The Keys to Success. DeMorgas, M., Botella, M., Eds.; Centre d'Estudis Olimpics i de l'Esport, Universitat Autonoma de Barcelona: Barcelona, SPAIN.

Miller, G. T., \& Spoolman, S. E. (2011). Living in the environment: principles, connections, and solutions; Nelson Education: Belmont, CA, USA.

Morphet, J. (1996). The real thing. Town Ctry. Plan., 65, 312-314.

Moroney, E. Thinking Big: Bringing Big Sport's Energy and Innovation to Education. Retrieved from https://canvas.harvard.edu/courses/2290/pages/module-4-big-sport-case-study.

Young, A. (2003). Avison Young Olympic Impact: Vancouver 2010 and the Industrial Real Estate Market. Avison Young: Vancouver, CANADA.

Pearce, C. (2015). How Olympic host cities are chosen. Retrieved from https://chrispearce52.wordpress.com/2015/12/27/how-olympic-host-cities-are-chosen/.

Price Waterhouse Coopers (2002). Business and Economic Benefits of the Sydney 2000 Games: A Collation of Evidence..NSW Department of State and Regional Development: Sydney, AUSTRALIA.

Olympic Games Candidature Process. Retrieved from https:/www.olympic.org/all-about-thecandidature-process.

Olympic Games Candidatures - Beyond 2024. Retrieved from https://www.olympic.org/olympicgames-candidatures-beyond-2024.

Ritchie, J. B., \& Smith, B. H. (1991). The impact of a mega-event on host region awareness: A longitudinal study. Journal of Travel Research, 30, 3-10.

Ruthheiser, D. (2000). Imagineering Atlanta; Verso: Brooklyn, NY, USA.

Scandizzo, P. L., Pierleoni, M. R. (2017). Assessing the olympic games: The economic impact and beyond. Journal of Economic Surveys, Article in Process.

State of Utah (2000). 2002 Olympic Winter Games. Retrieved from http://www.pages.drexel.edu/ rosenl/sports\%20Folder/Utah\%20Economic\%20Impact\%20Olympi cs\%202002.pdf.

Stevens, T., \& Bevan, T. (1999). Olympic legacy. Sport Management, 19(9), 16-19.

Schmitz, J. K. (2004). Ambush marketing: The off-field competition at the Olympic Games. Northwestern Journal of Technology and Intellectual Property, 3, 203-208.

Tudge, R. T. (2003). The impact of the Olympics on existing travel in Sydney. Traffic Engineerind ans Control, 44(1), 28-30. 
Warner, C. (2016). Here's How Olympic Host Cities Are Chosen. Retrieved from https://www.bustle.com/articles/178115-how-are-olympic-host-cities-chosen-the-rio-games-havebeen-a-long-time-in-the.

Wang, T.-C., \& Lee, H.-D. (2009). Developing a fuzzy TOPSIS approach based on subjective weights and objective weights. Expert Systems with Applications, 36(5), 8980-8985.

Zavadskas, E. K., \& Kaklauskas, A. (1996). Pastatu sistemotech-ninis ivertinimas [Multiple criteria evaluation of buildings]; Technika: Vilnius, LITHUANIA.

\section{Data Sources}

1. TSI (2017). Gross Domestic Product Per Capita by Provinces, 2014, Turkish Statistical Institute, Ankara, http://www.tuik.gov.tr/PreTablo.do?alt id=1075

2. TSI (2017). Transportation Statistics, Turkish Statistical Institute, Ankara, http://www.tuik.gov.tr/PreTablo.do?alt id=1051

3. MYS (2017). Numerical Distribution of Sports Clubs throughout Turkey in 2016. Ministry of Youth and Sports, Ankara, https://sgm.gsb.gov.tr/Public/Edit/.../2016/SPOR\%20KULÜPLERI\%2020072016.xls

4. MCT (2017). The Archeological Site of Cities, Ministry of Culture and Tourism General Directorate, http://www.kulturvarliklari.gov.tr/TR,44974/illere-gore-sit-alanlari-istatistigi.html

5. MCT (2017). Facilities with Tourism Certificate, Ministry of Culture and Tourism General Directorate of Investments and Operations, http://yigm.kulturturizm.gov.tr/TR,9860/turizmbelgeli-tesisler.html

6. MFWM (2017). Forest Asset According to Cities, Ministry of Forestry and Water Management, Ankara, https://www.ogm.gov.tr/Sayfalar/Ormanlarimiz/Illere-Gore-Orman-Varligi.aspx

7. MS (2017). Official Statistics: Average temperature data of 1927-2016, Turkish State Meteorological Service, Ankara, https://www.mgm.gov.tr/veridegerlendirme/il-ve-ilceleristatistik.aspx?k=A

8. ICT (2017). Annual City Statistics, Information Technology Agency (2017) https://www.btk.gov.tr/File/?path=ROOT\%2f1\%2fDocuments\%2fSayfalar\%2fll_Istatistikleri\%2f Ehsyib (2011-2016).pdf

9. BAT (2017). Information by Cities and Zones, The Banks Association of Turkey, İstanbul, https://www.tbb.org.tr/tr/bankacilik/banka-ve-sektor-bilgileri/veri-sorgulama-sistemi/illere-vebolgelere-gore-bilgiler/73

10. Energy Atlas (2017). Installed Capacity of Cities and Production and Consumption Information, http://www.enerjiatlasi.com/sehir/

11. GDS (2017). Police Statistics, General Directorate of Security, Ankara.

12. TSI (2017). Health Statistics. 2014, Turkish Statistical Institute, Ankara, http://www.tuik.gov.tr/PreTablo.do?alt_id=1095

13. EUM (2017). Ministry of Environment and Urban. Geographic Information Map. http://www.havaizleme.gov.tr/Default.ltr.aspx 


\section{Appendix A}

\begin{tabular}{|c|c|c|c|c|c|c|c|}
\hline \multirow[b]{2}{*}{ Criteria } & \multicolumn{7}{|c|}{ General Concept of Games, Facilities and Sports Experience } \\
\hline & $\begin{array}{c}\text { Swimming } \\
\text { Pools/Pop. } \\
\underset{3}{ }\end{array}$ & $\begin{array}{c}\text { Soccer } \\
\text { Field/Pop. } \\
\underset{3}{\text { s. }}\end{array}$ & 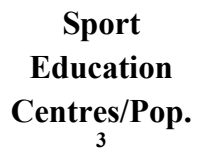 & $\begin{array}{c}\text { Sports } \\
\text { Hall/Pop. } \\
\underset{3}{ }\end{array}$ & $\underset{3}{\text { Stadium}} /$ Pop. & $\begin{array}{c}\text { International } \\
\quad \text { Sports } \\
\underset{3}{\text { Organizations/Pop. }} \\
\underset{3}{ }\end{array}$ & $\begin{array}{c}\text { Sports } \\
\text { Club/Pop. } \\
\underset{3}{3}\end{array}$ \\
\hline Adana & $2,3 \mathrm{E}-06$ & $1,5 \mathrm{E}-05$ & $4,1 \mathrm{E}-06$ & 7,3E-06 & $3,6 \mathrm{E}-06$ & $9,1 \mathrm{E}-07$ & $1,6 \mathrm{E}-04$ \\
\hline Ankara & $9,4 \mathrm{E}-07$ & $3,9 \mathrm{E}-06$ & $1,1 \mathrm{E}-06$ & $6,5 \mathrm{E}-06$ & $5,6 \mathrm{E}-07$ & $1,1 \mathrm{E}-06$ & $2,1 \mathrm{E}-04$ \\
\hline Antalya & $8,6 \mathrm{E}-07$ & $8,6 \mathrm{E}-07$ & $1,3 \mathrm{E}-06$ & 3,9E-06 & $2,6 \mathrm{E}-06$ & $1,4 \mathrm{E}-05$ & $1,7 \mathrm{E}-04$ \\
\hline Aydin & $2,8 \mathrm{E}-06$ & $2,2 \mathrm{E}-05$ & $2,8 \mathrm{E}-06$ & $1,5 \mathrm{E}-05$ & $6,6 \mathrm{E}-06$ & $9,4 \mathrm{E}-07$ & $2,3 \mathrm{E}-04$ \\
\hline Balıkesir & $1,7 \mathrm{E}-06$ & $7,5 \mathrm{E}-06$ & $3,3 \mathrm{E}-06$ & $8,4 \mathrm{E}-06$ & $9,2 \mathrm{E}-06$ & $1,7 \mathrm{E}-06$ & $2,0 \mathrm{E}-04$ \\
\hline Bursa & $1,4 \mathrm{E}-06$ & $1,0 \mathrm{E}-06$ & $2,8 \mathrm{E}-06$ & $7,6 \mathrm{E}-06$ & $5,2 \mathrm{E}-06$ & $1,4 \mathrm{E}-06$ & $1,9 \mathrm{E}-04$ \\
\hline Denizli & $4,0 \mathrm{E}-06$ & $1,7 \mathrm{E}-05$ & $9,9 \mathrm{E}-07$ & $1,9 \mathrm{E}-05$ & $2,0 \mathrm{E}-06$ & $9,9 \mathrm{E}-07$ & $1,4 \mathrm{E}-04$ \\
\hline Diyarbakır & $1,8 \mathrm{E}-06$ & $9,0 \mathrm{E}-06$ & $4,2 \mathrm{E}-06$ & $9,0 \mathrm{E}-06$ & $1,2 \mathrm{E}-06$ & $6,0 \mathrm{E}-07$ & $8,0 \mathrm{E}-05$ \\
\hline Erzurum & $2,6 \mathrm{E}-06$ & $1,7 \mathrm{E}-05$ & $7,9 \mathrm{E}-06$ & $3,8 \mathrm{E}-05$ & $5,2 \mathrm{E}-06$ & $3,9 \mathrm{E}-06$ & $2,2 \mathrm{E}-04$ \\
\hline Eskişehir & $3,6 \mathrm{E}-06$ & $1,2 \mathrm{E}-05$ & $2,4 \mathrm{E}-06$ & $1,8 \mathrm{E}-05$ & $3,6 \mathrm{E}-06$ & $1,2 \mathrm{E}-06$ & 2,2E-04 \\
\hline Gaziantep & $2,0 \mathrm{E}-06$ & $2,0 \mathrm{E}-06$ & $1,5 \mathrm{E}-06$ & $6,1 \mathrm{E}-06$ & $3,5 \mathrm{E}-06$ & $1,0 \mathrm{E}-06$ & $1,0 \mathrm{E}-04$ \\
\hline Hatay & $3,2 \mathrm{E}-06$ & $1,2 \mathrm{E}-05$ & $3,2 \mathrm{E}-06$ & $1,7 \mathrm{E}-05$ & 7,7E-06 & $6,4 \mathrm{E}-07$ & $1,3 \mathrm{E}-04$ \\
\hline İstanbul & $8,1 \mathrm{E}-07$ & $1,2 \mathrm{E}-06$ & $6,8 \mathrm{E}-07$ & $5,2 \mathrm{E}-06$ & $2,6 \mathrm{E}-06$ & $2,9 \mathrm{E}-06$ & $1,1 \mathrm{E}-04$ \\
\hline İzmir & $7,1 \mathrm{E}-07$ & $5,4 \mathrm{E}-06$ & $1,4 \mathrm{E}-06$ & $1,1 \mathrm{E}-05$ & $4,7 \mathrm{E}-06$ & $2,8 \mathrm{E}-06$ & $1,9 \mathrm{E}-04$ \\
\hline Kahramanmaraş & $2,7 \mathrm{E}-06$ & $1,1 \mathrm{E}-05$ & $4,5 \mathrm{E}-06$ & $1,5 \mathrm{E}-05$ & $3,6 \mathrm{E}-06$ & $1,8 \mathrm{E}-06$ & $1,0 \mathrm{E}-04$ \\
\hline Kayseri & $1,5 \mathrm{E}-06$ & $6,6 \mathrm{E}-06$ & $3,7 \mathrm{E}-06$ & $1,2 \mathrm{E}-05$ & $9,6 \mathrm{E}-06$ & $7,4 \mathrm{E}-07$ & $1,4 \mathrm{E}-04$ \\
\hline Kocaeli & $1,6 \mathrm{E}-06$ & $4,4 \mathrm{E}-06$ & $3,8 \mathrm{E}-06$ & $1,1 \mathrm{E}-05$ & $7,1 \mathrm{E}-06$ & $1,6 \mathrm{E}-06$ & $1,8 \mathrm{E}-04$ \\
\hline Konya & $2,3 \mathrm{E}-06$ & $1,8 \mathrm{E}-05$ & $1,9 \mathrm{E}-06$ & $1,4 \mathrm{E}-05$ & $3,2 \mathrm{E}-06$ & $4,6 \mathrm{E}-07$ & $1,1 \mathrm{E}-04$ \\
\hline Malatya & $5,1 \mathrm{E}-06$ & $4,2 \mathrm{E}-05$ & $3,8 \mathrm{E}-06$ & $1,5 \mathrm{E}-05$ & $2,6 \mathrm{E}-06$ & $3,8 \mathrm{E}-06$ & $2,0 \mathrm{E}-04$ \\
\hline Manisa & $2,1 \mathrm{E}-06$ & $6,4 \mathrm{E}-06$ & $3,6 \mathrm{E}-06$ & $1,5 \mathrm{E}-05$ & $1,1 \mathrm{E}-05$ & 7,2E-07 & $1,7 \mathrm{E}-04$ \\
\hline Mardin & $1,3 \mathrm{E}-06$ & $1,4 \mathrm{E}-05$ & $2,5 \mathrm{E}-06$ & $1,0 \mathrm{E}-05$ & $3,8 \mathrm{E}-06$ & $1,3 \mathrm{E}-06$ & $1,1 \mathrm{E}-04$ \\
\hline Mersin & $5,6 \mathrm{E}-07$ & $3,4 \mathrm{E}-06$ & $5,6 \mathrm{E}-07$ & $4,5 \mathrm{E}-06$ & $2,8 \mathrm{E}-06$ & 2,3E-06 & $1,9 \mathrm{E}-04$ \\
\hline Muğla & $2,2 \mathrm{E}-06$ & $1,4 \mathrm{E}-05$ & $4,3 \mathrm{E}-06$ & 1,9E-05 & $1,6 \mathrm{E}-05$ & $4,3 \mathrm{E}-06$ & $2,1 \mathrm{E}-04$ \\
\hline Ordu & $1,3 \mathrm{E}-06$ & $8,0 \mathrm{E}-06$ & $1,3 \mathrm{E}-06$ & $1,2 \mathrm{E}-05$ & $1,2 \mathrm{E}-05$ & $1,3 \mathrm{E}-06$ & $1,8 \mathrm{E}-04$ \\
\hline Sakarya & $2,0 \mathrm{E}-06$ & $2,0 \mathrm{E}-05$ & $6,1 \mathrm{E}-06$ & 2,3E-05 & $1,8 \mathrm{E}-05$ & $2,0 \mathrm{E}-06$ & $2,5 \mathrm{E}-04$ \\
\hline Samsun & $3,9 \mathrm{E}-06$ & $1,5 \mathrm{E}-05$ & $1,2 \mathrm{E}-05$ & $3,6 \mathrm{E}-05$ & $6,2 \mathrm{E}-06$ & $1,5 \mathrm{E}-06$ & $2,1 \mathrm{E}-04$ \\
\hline Şanlıurfa & $1,0 \mathrm{E}-06$ & $3,6 \mathrm{E}-06$ & $2,6 \mathrm{E}-06$ & 4,1E-06 & $1,5 \mathrm{E}-06$ & $5,2 \mathrm{E}-07$ & $5,2 \mathrm{E}-05$ \\
\hline Tekirdağ & $2,1 \mathrm{E}-06$ & $1,5 \mathrm{E}-05$ & $1,0 \mathrm{E}-06$ & $1,2 \mathrm{E}-05$ & $5,1 \mathrm{E}-06$ & $1,0 \mathrm{E}-06$ & 2,1E-04 \\
\hline Trabzon & $2,6 \mathrm{E}-06$ & $1,9 \mathrm{E}-05$ & $5,1 \mathrm{E}-06$ & $2,1 \mathrm{E}-05$ & $9,0 \mathrm{E}-06$ & $3,8 \mathrm{E}-06$ & $3,0 \mathrm{E}-04$ \\
\hline Van & $1,8 \mathrm{E}-06$ & $1,1 \mathrm{E}-05$ & $2,7 \mathrm{E}-06$ & 1,1E-05 & $2,7 \mathrm{E}-06$ & $9,1 \mathrm{E}-07$ & $9,8 \mathrm{E}-05$ \\
\hline
\end{tabular}

Source: ${ }^{3}$ MYS (2017). Numerical Distribution of Sports Clubs throughout Turkey in 2016. Ministry of Youth and Sports, Ankara. 


\begin{tabular}{|c|c|c|c|c|c|c|}
\hline \multirow[b]{2}{*}{ Criteria } & \multicolumn{6}{|c|}{ Environment, Meteorology, Accommodation and Transportation } \\
\hline & $\begin{array}{c}\text { Average } \\
\text { Temperature }{ }^{0} \mathrm{C} \\
(\text { optim.20.6) }\end{array}$ & $\begin{array}{c}\text { Air } \\
\text { Pollution } \\
\text { Index }\end{array}$ & $\begin{array}{c}\text { Archaeological/ } \\
\text { Natural Protected } \\
\text { Areas/Pop. }{ }^{4}\end{array}$ & $\begin{array}{c}\text { Forest } \\
\underset{6}{\text { Area/Pop. }}\end{array}$ & $\begin{array}{c}\text { Number } \\
\text { Of Beds } \\
\text { With Tourism } \\
\text { Operation } \\
\text { Certificated/Pop. } \\
5\end{array}$ & $\begin{array}{l}\text { Number of } \\
\text { Inc. } \\
\text { passengers to } \\
\underset{2}{\text { Airport/Pop. }}\end{array}$ \\
\hline Adana & 1 & $6,4 \mathrm{E}+01$ & $1,7 \mathrm{E}-04$ & $2,3 \mathrm{E}-01$ & $3,3 \mathrm{E}-03$ & $1,1 \mathrm{E}-02$ \\
\hline Ankara & 2 & $6,6 \mathrm{E}+01$ & $1,1 \mathrm{E}-04$ & $7,4 \mathrm{E}-02$ & $5,0 \mathrm{E}-03$ & $1,5 \mathrm{E}-02$ \\
\hline Antalya & 1 & $5,5 \mathrm{E}+01$ & $3,5 \mathrm{E}-04$ & $4,8 \mathrm{E}-01$ & $1,8 \mathrm{E}-01$ & $3,4 \mathrm{E}+00$ \\
\hline Aydın & 1 & $3,8 \mathrm{E}+01$ & $2,0 \mathrm{E}-04$ & 2,9E-01 & $2,5 \mathrm{E}-02$ & $0,0 \mathrm{E}+00$ \\
\hline Balıkesir & 2 & $3,8 \mathrm{E}+01$ & $2,0 \mathrm{E}-04$ & $5,5 \mathrm{E}-01$ & $7,8 \mathrm{E}-03$ & $3,3 \mathrm{E}-04$ \\
\hline Bursa & 2 & $6,3 \mathrm{E}+01$ & $8,6 \mathrm{E}-05$ & 1,7E-01 & $3,6 \mathrm{E}-03$ & $3,1 \mathrm{E}-03$ \\
\hline Denizli & 1 & $7,4 \mathrm{E}+01$ & $2,3 \mathrm{E}-04$ & $5,6 \mathrm{E}-01$ & $6,7 \mathrm{E}-03$ & $2,2 \mathrm{E}-03$ \\
\hline Diyarbakır & 1 & $4,8 \mathrm{E}+01$ & 1,7E-04 & $2,1 \mathrm{E}-01$ & 1,9E-03 & $4,3 \mathrm{E}-03$ \\
\hline Erzurum & 1 & $3,6 \mathrm{E}+01$ & $1,5 \mathrm{E}-04$ & $3,0 \mathrm{E}-01$ & $3,4 \mathrm{E}-03$ & $1,4 \mathrm{E}-02$ \\
\hline Eskişehir & 1 & $2,6 \mathrm{E}+01$ & $6,3 \mathrm{E}-04$ & 4,2E-01 & $5,0 \mathrm{E}-03$ & $2,6 \mathrm{E}-03$ \\
\hline Gaziantep & 1 & $3,0 \mathrm{E}+01$ & $1,4 \mathrm{E}-04$ & $4,2 \mathrm{E}-02$ & 4,9E-03 & $5,1 \mathrm{E}-03$ \\
\hline Hatay & 1 & $2,9 \mathrm{E}+01$ & $2,5 \mathrm{E}-04$ & $1,4 \mathrm{E}-01$ & 2,9E-03 & $3,8 \mathrm{E}-03$ \\
\hline İstanbul & 2 & $2,9 \mathrm{E}+01$ & $7,1 \mathrm{E}-06$ & $1,6 \mathrm{E}-02$ & $7,0 \mathrm{E}-03$ & $3,2 \mathrm{E}-02$ \\
\hline İzmir & 1 & $3,4 \mathrm{E}+01$ & $1,7 \mathrm{E}-04$ & 1,1E-01 & $8,4 \mathrm{E}-03$ & $1,0 \mathrm{E}-01$ \\
\hline Kahramanmaraş & 1 & $6,4 \mathrm{E}+01$ & $2,1 \mathrm{E}-04$ & $4,6 \mathrm{E}-01$ & 2,9E-03 & $0,0 \mathrm{E}+00$ \\
\hline Kayseri & 1 & $5,5 \mathrm{E}+01$ & $3,3 \mathrm{E}-04$ & 7,9E-02 & $2,4 \mathrm{E}-03$ & $6,3 \mathrm{E}-02$ \\
\hline Kocaeli & 2 & $5,1 \mathrm{E}+01$ & $4,8 \mathrm{E}-05$ & $8,0 \mathrm{E}-02$ & 3,9E-03 & $0,0 \mathrm{E}+00$ \\
\hline Konya & 2 & $4,2 \mathrm{E}+01$ & $4,3 \mathrm{E}-04$ & $2,3 \mathrm{E}-01$ & $2,6 \mathrm{E}-03$ & $1,2 \mathrm{E}-02$ \\
\hline Malatya & 1 & $5,3 E+01$ & $1,7 \mathrm{E}-04$ & $2,4 \mathrm{E}-01$ & $3,0 \mathrm{E}-03$ & $7,0 \mathrm{E}-03$ \\
\hline Manisa & 1 & $5,6 \mathrm{E}+01$ & $2,7 \mathrm{E}-04$ & $3,8 \mathrm{E}-01$ & $1,8 \mathrm{E}-03$ & $0,0 \mathrm{E}+00$ \\
\hline Mardin & 1 & $1,0 \mathrm{E}+01$ & $2,3 \mathrm{E}-04$ & $1,6 \mathrm{E}-01$ & $2,4 \mathrm{E}-03$ & $0,0 \mathrm{E}+00$ \\
\hline Mersin & 1 & $7,9 \mathrm{E}+01$ & $3,1 \mathrm{E}-04$ & $3,9 \mathrm{E}-01$ & 4,7E-03 & $0,0 \mathrm{E}+00$ \\
\hline Muğla & 2 & $4,2 \mathrm{E}+01$ & $9,5 \mathrm{E}-04$ & $9,1 \mathrm{E}-01$ & $1,2 \mathrm{E}-01$ & $2,0 \mathrm{E}+00$ \\
\hline Ordu & 2 & $5,9 \mathrm{E}+01$ & $5,2 \mathrm{E}-05$ & $2,7 \mathrm{E}-01$ & $3,5 \mathrm{E}-03$ & $0,0 \mathrm{E}+00$ \\
\hline Sakarya & 2 & $7,9 \mathrm{E}+01$ & $4,0 \mathrm{E}-05$ & $2,1 \mathrm{E}-01$ & $1,6 \mathrm{E}-03$ & $0,0 \mathrm{E}+00$ \\
\hline Samsun & 2 & $6,8 \mathrm{E}+01$ & $1,2 \mathrm{E}-04$ & $3,0 \mathrm{E}-01$ & $2,6 \mathrm{E}-03$ & 8,7E-03 \\
\hline Şanlıurfa & 1 & $3,1 \mathrm{E}+01$ & $3,7 \mathrm{E}-04$ & $4,6 \mathrm{E}-03$ & $1,2 \mathrm{E}-03$ & $3,1 \mathrm{E}-03$ \\
\hline Tekirdağ & 2 & $2,9 \mathrm{E}+01$ & $2,0 \mathrm{E}-04$ & 1,1E-01 & $3,0 \mathrm{E}-03$ & $1,6 \mathrm{E}-03$ \\
\hline Trabzon & 2 & $3,1 \mathrm{E}+01$ & $2,3 \mathrm{E}-05$ & $2,5 \mathrm{E}-01$ & 7,9E-03 & $2,7 \mathrm{E}-02$ \\
\hline Van & 1 & $4,4 \mathrm{E}+01$ & $8,5 \mathrm{E}-05$ & $2,6 \mathrm{E}-02$ & 1,7E-03 & $1,4 \mathrm{E}-03$ \\
\hline
\end{tabular}

Source: ${ }^{2}$ TSI (2017). Transportation Statistics, Turkish Statistical Institute, Ankara. ${ }^{4}$ MCT (2017). The Archeological Site of Cities, Ministry of Culture and Tourism General Directorate. ${ }^{5}$ MCT (2017). Facilities with Tourism Certificate, Ministry of Culture and Tourism General Directorate of Investments and Operations. ${ }^{13}$ EUM (2017). Ministry of Environment and Urban. Geographic Information Map.

Note: $\% 10$ Tolerance value for Average Temperature $\left(20,6{ }^{\circ} \mathrm{C}\right)$ has been considered. That means; cities which have average temperature between $18,54{ }^{\circ} \mathrm{C}$ and $22,66{ }^{\circ} \mathrm{C}$ have taken 2 points in the analysis. The others have taken 1 point in the analysis. 


\section{Appendix C}

\begin{tabular}{|c|c|c|c|c|c|c|}
\hline \multirow[b]{2}{*}{ Criteria } & \multicolumn{6}{|c|}{ Medical Services and Safety } \\
\hline & $\begin{array}{c}\text { Total } \\
\text { physician/Pop. } \\
112\end{array}$ & Nurse/Pop. ${ }^{12}$ & $\begin{array}{c}\text { Health } \\
\text { officer/Pop. }{ }^{12}\end{array}$ & $\underset{12}{\text { Pharmacist/Pop. }}$ & $\begin{array}{c}\text { Number of } \\
\text { hospital } \\
\text { beds/Pop. }{ }^{12}\end{array}$ & $\begin{array}{c}\text { Number of } \\
\text { Police/Pop. }{ }^{11}\end{array}$ \\
\hline Adana & 0,002 & 0,002 & 0,002 & 0,000 & 0,003 & 0,003 \\
\hline Ankara & 0,003 & 0,003 & 0,002 & 0,000 & 0,003 & 0,003 \\
\hline Antalya & 0,002 & 0,002 & 0,002 & 0,000 & 0,002 & 0,003 \\
\hline Aydin & 0,002 & 0,002 & 0,002 & 0,000 & 0,003 & 0,003 \\
\hline Balıkesir & 0,001 & 0,002 & 0,002 & 0,000 & 0,003 & 0,003 \\
\hline Bursa & 0,002 & 0,002 & 0,002 & 0,000 & 0,002 & 0,003 \\
\hline Denizli & 0,002 & 0,002 & 0,002 & 0,000 & 0,003 & 0,002 \\
\hline Diyarbakır & 0,002 & 0,002 & 0,001 & 0,000 & 0,003 & 0,003 \\
\hline Erzurum & 0,002 & 0,002 & 0,002 & 0,000 & 0,005 & 0,003 \\
\hline Eskişehir & 0,002 & 0,003 & 0,003 & 0,000 & 0,004 & 0,003 \\
\hline Gaziantep & 0,001 & 0,002 & 0,001 & 0,000 & 0,002 & 0,002 \\
\hline Hatay & 0,001 & 0,002 & 0,002 & 0,000 & 0,002 & 0,002 \\
\hline İstanbul & 0,002 & 0,002 & 0,001 & 0,000 & 0,002 & 0,003 \\
\hline İzmir & 0,002 & 0,002 & 0,002 & 0,000 & 0,003 & 0,003 \\
\hline Kahramanmaraş & 0,001 & 0,002 & 0,002 & 0,000 & 0,002 & 0,002 \\
\hline Kayseri & 0,002 & 0,002 & 0,002 & 0,000 & 0,003 & 0,003 \\
\hline Kocaeli & 0,002 & 0,002 & 0,002 & 0,000 & 0,002 & 0,002 \\
\hline Konya & 0,002 & 0,002 & 0,002 & 0,000 & 0,003 & 0,002 \\
\hline Malatya & 0,002 & 0,003 & 0,002 & 0,000 & 0,003 & 0,003 \\
\hline Manisa & 0,002 & 0,002 & 0,002 & 0,000 & 0,003 & 0,002 \\
\hline Mardin & 0,001 & 0,001 & 0,001 & 0,000 & 0,001 & 0,003 \\
\hline Mersin & 0,001 & 0,002 & 0,002 & 0,000 & 0,002 & 0,003 \\
\hline Muğla & 0,002 & 0,002 & 0,002 & 0,001 & 0,002 & 0,002 \\
\hline Ordu & 0,001 & 0,002 & 0,002 & 0,000 & 0,002 & 0,002 \\
\hline Sakarya & 0,001 & 0,001 & 0,002 & 0,000 & 0,002 & 0,002 \\
\hline Samsun & 0,002 & 0,002 & 0,002 & 0,000 & 0,003 & 0,002 \\
\hline Şanlıurfa & 0,001 & 0,001 & 0,001 & 0,000 & 0,001 & 0,002 \\
\hline Tekirdağ & 0,001 & 0,001 & 0,002 & 0,000 & 0,003 & 0,002 \\
\hline Trabzon & 0,002 & 0,003 & 0,003 & 0,000 & 0,004 & 0,002 \\
\hline Van & 0,001 & 0,001 & 0,001 & 0,000 & 0,002 & 0,003 \\
\hline
\end{tabular}

Source: ${ }^{11}$ GDS (2017). Police Statistics, General Directorate of Security, Ankara. ${ }^{12}$ TSI (2017). Health Statistics. 2014, Turkish Statistical Institute, Ankara, 


\section{Appendix D}

\begin{tabular}{|c|c|c|c|c|c|c|c|}
\hline \multirow[b]{2}{*}{ Criteria } & \multicolumn{7}{|c|}{ Telecommunication, Energy and Economy } \\
\hline & $\underset{8}{\text { Payphone }}$ & $\underset{8}{\text { Broadcast }}$ & $\underset{8}{\text { Fiberoptics }}$ & $\begin{array}{c}\text { Energy } \\
\text { Production } \\
\text { /Consumption } \\
\text { Rate }^{10} \\
\end{array}$ & $\begin{array}{c}\text { The } \\
\text { Number } \\
\text { Of ATM } \\
9 \\
\end{array}$ & $\begin{array}{c}\text { The } \\
\text { Number } \\
\text { of } \\
\text { POS } 9 \\
\end{array}$ & $\begin{array}{c}\text { Per Capita } \\
\text { GDP }^{1}\end{array}$ \\
\hline Adana & 0,001 & 0,774 & 0,003 & 2,260 & 0,000 & 0,028 & 19381 \\
\hline Ankara & 0,001 & 0,895 & 0,004 & 0,700 & 0,001 & 0,037 & 36679 \\
\hline Antalya & 0,002 & 0,812 & 0,004 & 0,880 & 0,001 & 0,045 & 29692 \\
\hline Aydın & 0,001 & 0,706 & 0,003 & 1,630 & 0,001 & 0,037 & 19121 \\
\hline Balıkesir & 0,001 & 0,737 & 0,004 & 2,480 & 0,001 & 0,032 & 22197 \\
\hline Bursa & 0,001 & 0,795 & 0,003 & 0,490 & 0,001 & 0,028 & 29946 \\
\hline Denizli & 0,001 & 0,726 & 0,004 & 1,430 & 0,001 & 0,032 & 24771 \\
\hline Diyarbakır & 0,001 & 0,522 & 0,003 & 1,290 & 0,000 & 0,012 & 12799 \\
\hline Erzurum & 0,001 & 0,635 & 0,007 & 1,100 & 0,000 & 0,019 & 15441 \\
\hline Eskişehir & 0,001 & 0,809 & 0,006 & 0,670 & 0,001 & 0,029 & 28823 \\
\hline Gaziantep & 0,001 & 0,659 & 0,002 & 0,220 & 0,000 & 0,020 & 18788 \\
\hline Hatay & 0,001 & 0,713 & 0,002 & 1,530 & 0,000 & 0,020 & 16701 \\
\hline İstanbul & 0,001 & 1,039 & 0,002 & 0,180 & 0,001 & 0,049 & 21217 \\
\hline İzmir & 0,001 & 0,896 & 0,003 & 0,850 & 0,001 & 0,041 & 43645 \\
\hline Kahramanmaraş & 0,000 & 0,627 & 0,003 & 1,200 & 0,000 & 0,017 & 31178 \\
\hline Kayseri & 0,001 & 0,655 & 0,006 & 0,580 & 0,000 & 0,028 & 15764 \\
\hline Kocaeli & 0,001 & 0,782 & 0,003 & 0,370 & 0,001 & 0,030 & 23129 \\
\hline Konya & 0,001 & 0,693 & 0,003 & 0,060 & 0,000 & 0,028 & 43520 \\
\hline Malatya & 0,001 & 0,642 & 0,005 & 0,100 & 0,000 & 0,020 & 20980 \\
\hline Manisa & 0,001 & 0,777 & 0,003 & 2,210 & 0,001 & 0,025 & 15206 \\
\hline Mardin & 0,000 & 0,609 & 0,003 & 0,010 & 0,000 & 0,011 & 24300 \\
\hline Mersin & 0,001 & 0,724 & 0,003 & 0,740 & 0,000 & 0,028 & 13285 \\
\hline Muğla & 0,001 & 0,786 & 0,006 & 3,600 & 0,001 & 0,054 & 27061 \\
\hline Ordu & 0,001 & 0,668 & 0,003 & 0,690 & 0,000 & 0,024 & 14575 \\
\hline Sakarya & 0,001 & 0,749 & 0,003 & 5,040 & 0,001 & 0,030 & 24359 \\
\hline Samsun & 0,001 & 0,747 & 0,003 & 2,540 & 0,000 & 0,031 & 19223 \\
\hline Şanlıurfa & 0,000 & 0,581 & 0,002 & 1,340 & 0,000 & 0,008 & 9773 \\
\hline Tekirdağ & 0,001 & 0,735 & 0,004 & 1,460 & 0,001 & 0,030 & 33258 \\
\hline Trabzon & 0,001 & 0,752 & 0,004 & 0,920 & 0,001 & 0,034 & 22073 \\
\hline Van & 0,001 & 0,522 & 0,003 & 0,100 & 0,000 & 0,009 & 9913 \\
\hline
\end{tabular}

Source: ${ }^{1}$ TSI (2017). Gross Domestic Product Per Capita by Provinces, 2014, Turkish Statistical Institute, Ankara. ${ }^{8}$ ICT (2017). Annual City Statistics, Information Technology Agency. ${ }^{9}$ BAT (2017). Information by Cities and Zones, The Banks Association of Turkey, İstanbul. ${ }^{10}$ Energy Atlas (2017). Installed Capacity of Cities and Production and Consumption Information.

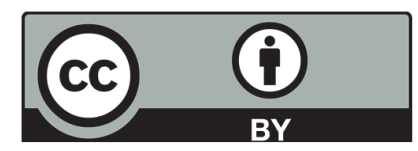

(C) 2019 by the authors; licensee Growing Science, Canada. This is an open access article distributed under the terms and conditions of the Creative Commons Attribution (CC-BY) license (http://creativecommons.org/licenses/by/4.0/). 